WSRC-TR-2001-00539

December 2001

WSRC-TR-2001-00539 (U)

\title{
STREAM II-V3: Revision for STREAM II-V2 to Include the Sedimentation Effects on a Release from H-Area (U)
}

\author{
K u $0-F u C h e n$ \\ Savannah River Technology Center
}

Publication Date: December 1, 2001

DOES NOT CONTAIN

UNCLASSIFIED CONTROLLED

NUCLEAR INFORMATION

ADC \&

Reviewing

Official:

Date:

Westinghouse Savannah River Company

Savannah River Site

Aiken, SC 29808

This document was prepared in connection with work done under Contract No. DE-AC09-96SR18500

with the U. S. Department of Energy 
This document was prepared in conjunction with work accomplished under Contract No. DE-AC09-96SR18500 with the U.S. Department of Energy.

\section{DISCLAIMER}

This report was prepared as an account of work sponsored by an agency of the United States Government. Neither the United States Government nor any agency thereof, nor any of their employees, makes any warranty, express or implied, or assumes any legal liability or responsibility for the accuracy, completeness, or usefulness of any information, apparatus, product or process disclosed, or represents that its use would not infringe privately owned rights. Reference herein to any specific commercial product, process or service by trade name, trademark, manufacturer, or otherwise does not necessarily constitute or imply its endorsement, recommendation, or favoring by the United States Government or any agency thereof. The views and opinions of authors expressed herein do not necessarily state or reflect those of the United States Government or any agency thereof.

This report has been reproduced directly from the best available copy.

Available for sale to the public, in paper, from: U.S. Department of Commerce, National Technical Information Service, 5285 Port Royal Road, Springfield, VA 22161

phone: (800) 553-6847

fax: (703) 605-6900

email: orders@ntis.fedworld.gov

online ordering: http://www.ntis.gov/support/index.html

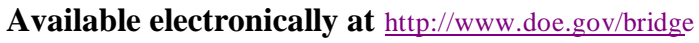

Available for a processing fee to U.S. Department of Energy and its contractors, in paper, from: U.S. Department of Energy, Office of Scientific and Technical Information, P.O. Box 62, Oak Ridge, TN 37831-0062

phone: (865)576-8401

fax: $(\mathbf{8 6 5}) 576-5728$

email: reportseadonis.osti.gov 
WSRC-TR-2001-00539

December 2001

DOCUMENT: $\quad$ WSRC-TR-2001-00539

TITLE: STREAM II-V3: Revision for STREAM II-V2 to Include the Sedimentation Effects on a Release from H-Area (U)

TASK:

TECHNICAL REVIEW

एक्ष

Robert L. Buckley

Date:

SRTC/Measurement Technology Department/Nonproliferation Technologies Section

APPROVALS

E.

R. P. Addis, Manager, ATG

Date:

SRTC/Measurement Technology Department/Nonproliferation Technologies Section

A. L. Boni, Manager, NTS

Date:

SRTC/Measurement Technology Department/Nonproliferation Technologies Section 
WSRC-TR-2001-00539

December 2001

(Blank Page) 


\begin{abstract}
STREAM II-V2, an aqueous transport module of the Savannah River Site emergency response Weather INformation Display (WIND) system, accounts for the effects of dilution, advection and dispersion. Although the model has the capability to account for nuclear decay, due to the short time interval of interest for emergency response, the effect of nuclear decay is very small and so it is not employed. The interactions between the sediment and radionuclides are controlled by the flow conditions and physical and chemical characteristics of the radionuclides and the sediment constituents. The STREAM II-V2 used in emergency response does not model the effects of sediment deposition/resuspension to minimize computing time. The effects of sedimentation on the cesium and plutonium transport in the Fourmile Branch were studied recently and the results from these studies indicated that the downstream cesium and plutonium peak concentrations were significantly reduced due to the effects of sedimentation.
\end{abstract}

The STREAM II-V2 was upgraded to account for the effect of sedimentation on aqueous transport of cesium and plutonium released from H-Area. The revised STREAM II-V2 is designated as STREAM II-V3. To minimize the computing time, STREAM II-V3 did not model the sedimentation process explicitly. Instead, STREAM II-V3 uses correction factors to account for the sedimentation effect. The correction factors were pre-determined by the model that simulates the sedimentation process explicitly. 


\section{TABLE OF CONTENTS}

1. Introduction 1

2. Implementation 2

2.1 Model without Sedimentation Effect 2

2.2 Model for Sedimentation Simulation 3

2.2.1 Benthic Segment Geometry 3

2.2.2 Diffusion Coefficient 3

2.2.3 Sediment (Solid) Concentration 3

2.2.4 Partition Coefficient for Sorption to Sediment 4

2.2.5 Deposition and Resuspension Velocities 4

3. Selection of Cases for Developing the Correction Factors 4

3.1 Release Location and Release Material Type 5

3.2 Release Time $\quad 5$

3.3 Release Quantity 5

3.4 Release Duration 5

3.5 Look-up Tables 5

4. Revision for STREAM II-V2 6

5. Conclusions

6. Reference 8 
WSRC-TR-2001-00539

December 2001

\section{LIST OF TABLES}

Table 1. Benthic Segment Geometry

Table 2. Cesium Peak Concentrations and Correction Factors as a Function of Release Quantity

Table 3. Cesium Correction Factors as a Function of Release Duration

Table 4. Cesium Correction Factors

Table 5. Plutonium Correction Factors

\section{LIST OF FIGURES}

Figure 1. Model Schematics for Fourmile Branch (not to scale)

Figure 2. Model Schematics for Fourmile Branch with Benthic Segment (not to scale)

Figure 3. Schematics of Modeled Physical-Chemical Features for Cesium (Plutonium) in Aqueous Transport 
WSRC-TR-2001-00539

December 2001

(Blank Page) 


\section{Introduction}

The major mechanisms of radioactive material transport and fate in surface water are 1) dilution, advection and dispersion of radionuclides by flow and surface waves, 2) radionuclide decay, and 3 ) interaction between sediment and radionuclides. The interactions between sediment and radionuclides include radionuclide adsorption by sediment, radionuclide desorption from sediment to water, transport of particulate radionuclides (those adsorbed by suspended sediment), deposition of particulate radionuclides to stream bed (benthic layer), and scouring of particulate radionuclides from stream bed (resuspension).

STREAM II-V2 [1], an aqueous transport module of the Savannah River Site (SRS) emergency response Weather INformation Display (WIND) system [2], accounts for the effects of dilution, advection and dispersion. Although the model has the capability to account for nuclear decay, due to the short time interval of interest for emergency response, the effect of nuclear decay is very small and so it is not employed. The interactions between the sediment and radionuclides are controlled by the flow conditions and physical and chemical characteristics of the radionuclides and the sediment constituents. The STREAM II-V2 used in emergency response does not model the effects of sediment deposition/resuspension to minimize computing time. The effects of sedimentation on the cesium and plutonium transport in the Fourmile Branch were studied $[3,4]$. The results from References 3 and 4 indicated that the downstream cesium and plutonium peak concentrations were significantly reduced due to the effects of sedimentation.

During the Technical Issues Review Meeting on July 26, 2001, Jim Hardeman of the Georgia Natural Resources Department raised a legitimate concern. His concern follows.

It is recognized that sedimentation has a significant affect on downstream pollutant concentrations $[3,4]$. The peak concentration predicted by the STREAM II-V2 that did not account for the sedimentation effect would be very conservative (the predicted value is higher than the actual value). For a small release it would not cause any practical problem. However, for a large spill, this conservatism might cause unwarranted alarm because the STREAM II-V2 output would be treated as true to the authorities and the press. The authorities could make a drastic decision based on the STREAM II-V2 output even though the actual peak concentrations would be significantly lower than the STREAM II-V2 predictions. To address this concern, the STREAM II-V2 was upgraded to account for the effects of sedimentation on aqueous transport of cesium and plutonium released from $\mathrm{H}$-Area. The reasons for the selection of the release location from H-Area and for using cesium and plutonium for the release materials are as follows.

i. The sources that could have potential to release a large volume of liquid waste 
containing radioactive isotopes are the High Level Waste (HLW) tanks in the HArea.

ii. The largest quantity of isotopes in the HLW tanks is cesium $\left(\approx 10^{7} \mathrm{Ci}\right)$.

iii. There are field data about the cesium transport in the Fourmile Branch available for model benchmarking [3].

iv. The plutonium inventory in the HLW tanks is very low $(<7 \mathrm{Ci})$. Although, the potential for a large release of plutonium is insignificant, the plutonium modeling was upgraded due to public perception about its toxicity.

2. Implementation

The computing time for modeling the sedimentation process is very long with respect to the emergency response needs. Therefore, a simplified method described below was used to minimize the computing time.

Step 1. Use STREAM II-V2 that does not model the sedimentation process to model the cesium transport from $\mathrm{H}$-area to the Savannah Water Plant.

Step 2. Use a model that includes the sedimentation process explicitly to model the cesium transport from $\mathrm{H}$-area to the Savannah Water Plant.

Step 3. Calculate the relative peak concentration reductions between the Steps 1 and 2 at selected downstream locations.

Step 4. Repeat Steps 1 to 3 for release in 12 different months because the flow in STREAM II-V2 is a function of month in which the release takes place.

Step 5. Generate a look-up table for peak concentration reductions as a function of month and downstream locations.

Step 6. Repeat Steps 1 to 5 for plutonium.

Step 7. Implement the look-up tables in the STREAM II.

For emergency response, the STREAM II transport calculation will not model the sedimentation process explicitly. Instead, the sedimentation effects will be accounted for by multiplying the correction factor obtained from the look-up table to the peak concentration calculated by the transport model that does not include the sedimentation process. The increment of computing time for this table look-up procedure will be insignificant.

\subsection{Model without Sedimentation Effect}

The model (Figure 1) described in the Reference 1 simulates the transport of a release from $\mathrm{H}$-Area. This model does not account for the sedimentation effect.

2.2 Model for Sedimentation Simulation 
Additional benthic segments (stream bed segment) were added beneath the water column segment, as shown in Figure 2, to model the deposition of sediment from the water column segment to the benthic segment and the resuspension of sediment from the benthic segment to the water column segment. Figure 3 shows the modeled mechanisms for cesium (or plutonium) transport in the water body. They are sorption and desorption between the dissolved and absorbed forms in the water column and benthic segments, deposition/resuspension mechanisms of the sediment between the water column and the benthic segments, and diffusive exchange of cesium (or plutonium) between the water column and pore water in the benthic segment. As indicated in Figure 3, additional input data are required to model the sediment deposition/resuspension effects. They are benthic segment geometry, diffusion coefficient between the water column and the benthic segments, sediment concentrations in the water column (suspended) and benthic segments, deposition (settling) and resuspension velocities, and cesium (or plutonium) partition coefficient. It was assumed that the initial cesium (or plutonium) concentrations in the water column and benthic segments were zero.

\subsubsection{Benthic Segment Geometry}

The area between the water column segment and the benthic segment is the benthic cross section area that is used to calculate diffusive exchange between the water column and the pore water in the benthic segment. The assumed benthic segment cross section areas are presented in Table 1. A typical benthic layer depth of $0.1 \mathrm{~m}$ was used for the model. The benthic segment volumes were calculated from the cross section area and the depth, as shown in Table 1.

\subsubsection{Diffusion Coefficient}

The typical range of the diffusion coefficient between the water column and the benthic layer is from $1.0 \mathrm{E}-05$ to $1.0 \mathrm{E}-08 \mathrm{~m}^{2} / \mathrm{s}$ [3]. A diffusion coefficient of $1.0 \mathrm{E}-08 \mathrm{~m}^{2} / \mathrm{s}$ was used in this study.

\subsubsection{Sediment (Solid) Concentrations}

In the 1978 Environmental Monitoring annual report for the Savannah River Plant [5], the measured minimum suspended solid concentration on Fourmile Branch at Road A-7 was 3 $\mathrm{mg} / \mathrm{l}$. The measured maximum suspended solid concentration was $150 \mathrm{mg} / \mathrm{l}$, and the measured mean suspended solid concentration was $20.667 \mathrm{mg} / \mathrm{l} .20 \mathrm{mg} / \mathrm{l}$ was used in this model as the suspended sediment concentrations in the water column segments. The average measured total suspended solid from 1989 to 1999 in the Savannah River is about $11 \mathrm{mg} / \mathrm{l}$ and is used in this model. The typical sediment concentration in the benthic segment is $1.0 \mathrm{E}+06 \mathrm{mg} / \mathrm{l}$. 


\subsubsection{Partition Coefficients for Sorption to Sediment}

A partition coefficient of 8,500 $\mathrm{ml} / \mathrm{g}$ was used for cesium as described in Reference 3 . From Reference 6, the plutonium partition coefficient at a sediment concentration of 860 $\mathrm{ppm}$ is $5,000 \mathrm{ml} / \mathrm{g}$. The sediment concentrations in the Savannah River and the Fourmile Branch are 11 and $20 \mathrm{ppm}$, respectively. The plutonium partition coefficient increases as the sediment concentration decreases [4]. Therefore, the plutonium partition coefficient for Savannah River would be larger than $5,000 \mathrm{ml} / \mathrm{g}$. However, due to lack of direct field (Fourmile Branch) measured data, it was decided that a plutonium partition of 5,000 ml/g would be used in this study for conservatism.

\subsubsection{Deposition and Resuspension Velocities}

The settling velocity of $20 \mathrm{~m} /$ day was estimated from the cesium transport study [3]. The resuspension velocities were 4.0E-04 m/day for Fourmile Branch, and 2.2 E-04 m/day for Savannah River. The resuspension velocities were selected to achieve a balance between deposition and resuspension, thereby maintaining a constant suspended sediment concentration of $20 \mathrm{mg} / \mathrm{l}$ in the water column segments for Fourmile Branch, and $11 \mathrm{mg} / \mathrm{l}$ in the water column segments for Savannah River.

\section{Selection of Parameters for Developing the Correction Factors}

This section describes the selection of parameters for developing the correction factors to be used by STREAM II-V2 to account for the sedimentation effect without explicitly modeling the sedimentation process. The input parameters for STREAM II-V2 are release location, release time, release material type, release quantity, and release duration. Therefore, the correction factor is expressed as Equation 1.

$\mathrm{F}(\mathrm{RL}, \mathrm{M}, \mathrm{T}, \mathrm{A}, \mathrm{D}, \mathrm{DL})=\frac{\mathrm{P}_{\mathrm{SD}}(\mathrm{RL}, \mathrm{M}, \mathrm{T}, \mathrm{A}, \mathrm{D}, \mathrm{DL})}{\mathrm{P}_{\mathrm{STII}}(\mathrm{RL}, \mathrm{M}, \mathrm{T}, \mathrm{A}, \mathrm{D}, \mathrm{DL})}$

where $\mathrm{F}$ is a correction factor and is a function of release location $(\mathrm{RL})$, release time $(\mathrm{M})$, release material type (T), release quantity (A), release duration (D), and downstream location (DL). $\mathrm{P}_{\mathrm{SD}}$ is the peak concentration calculated by the model that models the sedimentation process explicitly, and $\mathrm{P}_{\text {STII }}$ is the peak concentration calculated by the STREAM II-V2 that does not account for the sedimentation effect.

Equation 1 shows the parameters (release location, release time, release material type, release quantity, and release duration) required to calculate the correction factor. These parameters are determined in the following Sections.

3.1 Release Location and Release Material Type 
This project is to account for the sedimentation effect on aqueous transport of cesium and plutonium released from $\mathrm{H}$-Area. Therefore, the correction factor is set to 1 for release locations other than $\mathrm{H}$-Area or for release material types other than cesium and plutonium.

\subsection{Release Time}

Flow is an input parameter for aqueous transport calculations. The STREAM II-V2 input flows are derived from USGS measured flow records [7]. The input flow for the Savannah River is derived by averaging the measured daily mean flow by month from January 1, 1975 to December 31, 1995. The same method is used to derive input flows for the onsite streams except that the averaging period for the onsite streams are shorter to exclude the influence of reactor discharge flows. The averaging period for onsite streams is from January 1, 1990 to December 31, 1995. STREAM II-V2 uses the flow based on the release time (month) input by the user. Therefore, the correction factors vary as a function of month in which the release takes place. Therefore, the variation of the release time for the correction factor is from January to December.

\subsection{Release Quantity}

The aqueous transport is a linear system, and the downstream peak concentration is proportional to the release quantity. Table 2 presents peak concentrations simulated by the STREAM II-V2 model for the instance of no sedimentation effect, and the process of explicitly accounting for sedimentation process. For each of these model simulations, instantaneous releases of cesium of $1 \mathrm{~kg}$ and $10 \mathrm{~kg}$ are assumed. In addition, Table 2 shows that the correction factors are dependent on the month in which the release occurred and the downstream locations, but independent of the quantity released as long as the release of the material is instantaneous.

\subsection{Release Duration}

For the cases of constant material released for different duration times, the released material remains in the stream longer if the release duration increases. Therefore, there is a greater chance for the material to interact with the suspended sediment. This enhances the sedimentation effect, and results in lower peak concentrations and correction factors, as shown in Table 3. The three cases shown in Table 3 assume $1 \mathrm{~kg}$ of cesium released: (1) instantaneously, (2) over 300 minutes and, (3) over 600 minutes. Table 3 show that the correction factor decreases as the release duration increases.

\subsection{Look-Up Tables}

Based on the study shown in Sections 3.3 and 3.4, the scenario used to develop the correction factors for the look-up table is based on instantaneous release of $1 \mathrm{~kg}$ of cesium 
(or plutonium). The condition of releasing $1 \mathrm{~kg}$ (unit quantity) is selected for convenience since the correction factor is independent of the quantity released, as described in Section 3.3. Section 3.4 indicates that the correction factor decreases as the duration of release increases. Therefore, the condition of instantaneous release was selected to give a conservative result (higher peak concentration).

Equation 1 shows that the variables for the correction factor are release location, release material type, release quantity, release duration, release time, and downstream location. For this study, the release location is from H-Area; the release material type is cesium or plutonium; the release quantity is $1 \mathrm{~kg}$; and the release duration is instantaneous. The remaining variables are release time and downstream location.

Tables 4 and 5 present the correction factors as a function of month (release time) and downstream location for cesium and plutonium, respectively. The correction factors decrease when cesium (or plutonium) transports downstream because cesium (or plutonium) precipitates to the stream bed when it transports downstream.

The correction factor changes with flow. For the case of omitting the sedimentation effect, the downstream peak concentration decreases as flow increases because there is more dilution effect for the high flow conditions. For the cases of sedimentation process simulated, the downstream concentration decreases when flow decreases. The transient time becomes longer when flow decreases. Thus, there is a greater chance for the material to interact with the suspended sediment. This enhances the sedimentation effect, and results in lower peak concentrations. Therefore, the correction factor decreases as flow decreases. For the Savannah River, the high flow season is in February and March and the low flow season is in May and June. Therefore, the lowest correction factor is in May and the largest correction factor is in February or March, as shown in Tables 4 and 5.

\section{Revision for STREAM II-V2}

Tables 4 and 5 were implemented in STREAM II-V2 to account for the effect of sedimentation on the aqueous transport of cesium and plutonium released from H-Area. The upgraded STREAM II-V2 is designated as STREAM II-V3. The only change for the user input is that the user has an option to input additional release material types (cesium and plutonium). The correction factor is set to one internally for release location other than $\mathrm{H}$-Area or for release material types other than cesium and plutonium. For the case of a release location at $\mathrm{H}$-Area and a release material type of cesium or plutonium, the code will determine the correction factor based on the release time and downstream location. The downstream peak concentration is multiplied by the correction factor, as shown in Equation 2 , to account for the sedimentation effect.

$$
\mathrm{P}_{\mathrm{STII}-\mathrm{SD}}(\mathrm{M}, \mathrm{T}, \mathrm{DL})=\mathrm{F}(\mathrm{M}, \mathrm{T}, \mathrm{DL}) \mathrm{P}_{\mathrm{STII}}(\mathrm{M}, \mathrm{T}, \mathrm{DL})
$$


where $\mathrm{PS}_{\mathrm{TII}-\mathrm{SD}}$ is the peak concentration, calculated by the upgraded STEAM II-V3, including the sedimentation effect. $\mathrm{F}$ is correction factor, as shown in Tables 4 and 5 . $\mathrm{P}_{\text {STII }}$ is the peak concentration calculated by the STREAM II-V2 that does not account for the sedimentation effect. The variable $\mathrm{M}$ denotes the month (January to December), $\mathrm{T}$ is the release material type (cesium or plutonium), and DL is the downstream location (shown in Table 4).

\section{Conclusions}

The STREAM II-V2 was upgraded to account for the effect of sedimentation on the aqueous transport of cesium and plutonium released from $\mathrm{H}$-Area. The revised STREAM II-V2 is designated as STREAM II-V3. To minimize the computing time, STREAM II-V3 did not model the sedimentation process explicitly. Instead, STREAM II-V3 uses correction factors to account for the sedimentation effect. The correction factors were predetermined by the model that simulates the sedimentation process explicitly. The advantage of this table look-up method is a reduction in required computing time. The typical computing time for the table look-up model is about 5 minutes, and the computing time increases to 15 minutes for the explicit sedimentation model. The drawbacks of this table look-up method are conservatism built in the look-up table, as described in Section 3.5 and rigidity of the look-up table. The look-up table becomes invalid when the release and/or the downstream locations are changed. To resolve these shortfalls, it is recommended that the explicit model be used in the future when the computer speeds improve. 
6. References

1. Chen, Kuo-Fu, " Revision for STREAM II-V1 Input Files to Include Downstream Tributary Flows (U),” WSRC-TR-2001-00039, Savannah River Site, January 23, 2001.

2. Hunter, C. H., "Weather Information and Display (WIND) System User's Manual," WSRC-TM-90-14, Savannah River Site, 1990.

3. Chen, Kuo-Fu, "Modeling the Effect of Sedimentation on Cesium Transport in Fourmile Branch (U)," WSRC-TR-2000-00380, Savannah River Site, September 30, 2000.

4. Chen, Kuo-Fu, "The Effect of Sedimentation on Plutonium Transport in Fourmile Branch (U)," WSRC-TR-2001-00322, Savannah River Site, July 2, 2001.

5. C. Ashley and C. C. Zeigler, "Environmental Monitoring at the Savannah River Plant, Annual Report - 1978," Health Protection Department, Savannah River Plant, E. I. du Pont de Nemours and Company, Aiken, South Carolina, January 1981.

6. Mudge, S., J. Hamilton-Taylor, M. Kelly, and K. Bradshaw, "Laboratory Studies of Chemical Behavior of Plutonium Associated with Contaminated Estuarine Sediment," Journal Environmental Radioactivity 8, pp 217-237, 1988.

7. Chen, Kuo-Fu, "STREAM 2 for SRS Aqueous Release Emergency Response (U)," WSRC-TR-98-00234, Savannah River Site, June, 1998. 
WSRC-TR-2001-00539

December 2001

Table 1. Benthic Segment Geometry

Segment Number

$\begin{array}{cccc}\begin{array}{c}\text { Cross Section Area** } \\ \left(\mathrm{m}^{2}\right)\end{array} & \begin{array}{c}\text { Depth }^{+} \\ (\mathrm{m})\end{array} & \begin{array}{c}\text { Volume } \\ \left(\mathrm{m}^{3}\right)\end{array} & \begin{array}{c}\text { Diffusion Coefficient } \\ \left(\mathrm{m}^{2} / \mathrm{s}\right)\end{array} \\ 1125 & 0.1 & 112.5 & 1.0 \mathrm{E}-08 \\ 17602 & 0.1 & 1760.2 & 1.0 \mathrm{E}-08\end{array}$

**Area between water column segment and the benthic segment.

${ }^{+}$Depth of the benthic layer. 
Table 2. Cesium Peak Concentrations and Correction Factors as a Function of Release Quantity

Month

Downstream Location

In which

$\operatorname{Road}$ A

Savannah
River

US

STATE

Occurred

Peak Concentration (ppb)

Beaufort Jasper
Savannah

Water Plan

\section{STREAM II No Deposition}

Case 1: $1 \mathrm{~kg}$ cesium released instantaneously

\begin{tabular}{lcccccc} 
January & $3.23 \mathrm{E}+01$ & $1.12 \mathrm{E}-01$ & $9.04 \mathrm{E}-02$ & $7.05 \mathrm{E}-02$ & $6.81 \mathrm{E}-02$ & $6.71 \mathrm{E}-02$ \\
March & $2.67 \mathrm{E}+01$ & $8.61 \mathrm{E}-02$ & $6.69 \mathrm{E}-02$ & $5.39 \mathrm{E}-02$ & $5.24 \mathrm{E}-02$ & $5.17 \mathrm{E}-02$ \\
June & $3.65 \mathrm{E}+01$ & $1.31 \mathrm{E}-01$ & $1.08 \mathrm{E}-01$ & $8.75 \mathrm{E}-02$ & $8.44 \mathrm{E}-02$ & $8.31 \mathrm{E}-02$ \\
October & $2.98 \mathrm{E}+01$ & $1.37 \mathrm{E}-01$ & $1.11 \mathrm{E}-01$ & $9.01 \mathrm{E}-02$ & $8.63 \mathrm{E}-02$ & $8.49 \mathrm{E}-02$ \\
\multicolumn{7}{l}{} \\
\multicolumn{7}{l}{ Case 2: } \\
January & $3.23 \mathrm{Eg}+02$ & $1.12 \mathrm{E}+00$ & $9.04 \mathrm{E}-01$ & $7.05 \mathrm{E}-01$ & $6.81 \mathrm{E}-01$ & $6.71 \mathrm{E}-01$ \\
March & $2.67 \mathrm{E}+02$ & $8.61 \mathrm{E}-01$ & $6.69 \mathrm{E}-01$ & $5.39 \mathrm{E}-01$ & $5.24 \mathrm{E}-01$ & $5.17 \mathrm{E}-01$ \\
June & $3.65 \mathrm{E}+02$ & $1.31 \mathrm{E}+00$ & $1.08 \mathrm{E}+00$ & $8.75 \mathrm{E}-01$ & $8.44 \mathrm{E}-01$ & $8.31 \mathrm{E}-01$ \\
October & $2.98 \mathrm{E}+02$ & $1.37 \mathrm{E}+00$ & $1.11 \mathrm{E}+00$ & $9.01 \mathrm{E}-01$ & $8.63 \mathrm{E}-01$ & $8.49 \mathrm{E}-01$
\end{tabular}

\section{Sedimentation Process Modeled Explicitly}

Case 1: $1 \mathrm{~kg}$ cesium released instantaneously

\begin{tabular}{lcccccr} 
January & $5.14 \mathrm{E}-01$ & $1.87 \mathrm{E}-04$ & $1.31 \mathrm{E}-04$ & $8.44 \mathrm{E}-05$ & $7.61 \mathrm{E}-05$ & $7.27 \mathrm{E}-05$ \\
March & $4.88 \mathrm{E}-01$ & $2.48 \mathrm{E}-04$ & $1.75 \mathrm{E}-04$ & $1.23 \mathrm{E}-04$ & $1.14 \mathrm{E}-04$ & $1.10 \mathrm{E}-04$ \\
June & $2.76 \mathrm{E}-02$ & $3.78 \mathrm{E}-06$ & $2.54 \mathrm{E}-06$ & $1.52 \mathrm{E}-06$ & $1.32 \mathrm{E}-06$ & $1.24 \mathrm{E}-06$ \\
October & $1.56 \mathrm{E}-01$ & $6.97 \mathrm{E}-05$ & $4.73 \mathrm{E}-05$ & $2.95 \mathrm{E}-05$ & $2.57 \mathrm{E}-05$ & $2.42 \mathrm{E}-05$ \\
\multicolumn{7}{c}{} \\
Case 2: $10 \mathrm{~kg}$ cesium released instantaneously \\
January & $5.14 \mathrm{E}+00$ & $1.87 \mathrm{E}-03$ & $1.31 \mathrm{E}-03$ & $8.44 \mathrm{E}-04$ & $7.61 \mathrm{E}-04$ & $7.27 \mathrm{E}-04$ \\
March & $4.88 \mathrm{E}+00$ & $2.48 \mathrm{E}-03$ & $1.75 \mathrm{E}-03$ & $1.23 \mathrm{E}-03$ & $1.14 \mathrm{E}-03$ & $1.10 \mathrm{E}-03$ \\
June & $2.76 \mathrm{E}-01$ & $3.78 \mathrm{E}-05$ & $2.54 \mathrm{E}-05$ & $1.52 \mathrm{E}-05$ & $1.32 \mathrm{E}-05$ & $1.24 \mathrm{E}-05$ \\
October & $1.56 \mathrm{E}+00$ & $6.97 \mathrm{E}-04$ & $4.73 \mathrm{E}-04$ & $2.95 \mathrm{E}-04$ & $2.57 \mathrm{E}-04$ & $2.42 \mathrm{E}-04$
\end{tabular}

\section{Correction Factor}

Case 1: $1 \mathrm{~kg}$ cesium released instantaneously

\begin{tabular}{lrrrrrr} 
January & $1.591 \mathrm{E}-02$ & $1.670 \mathrm{E}-03$ & $1.449 \mathrm{E}-03$ & $1.197 \mathrm{E}-03$ & $1.117 \mathrm{E}-03$ & $1.083 \mathrm{E}-03$ \\
March & $1.828 \mathrm{E}-02$ & $2.880 \mathrm{E}-03$ & $2.616 \mathrm{E}-03$ & $2.282 \mathrm{E}-03$ & $2.176 \mathrm{E}-03$ & $2.128 \mathrm{E}-03$ \\
June & $7.562 \mathrm{E}-04$ & $2.885 \mathrm{E}-05$ & $2.352 \mathrm{E}-05$ & $1.737 \mathrm{E}-05$ & $1.564 \mathrm{E}-05$ & $1.492 \mathrm{E}-05$ \\
October & $5.235 \mathrm{E}-03$ & $5.088 \mathrm{E}-04$ & $4.261 \mathrm{E}-04$ & $3.274 \mathrm{E}-04$ & $2.978 \mathrm{E}-04$ & $2.850 \mathrm{E}-04$ \\
\multicolumn{7}{c}{} \\
Case 2: $10 \mathrm{~kg}$ cesium released instantaneously \\
January & $1.591 \mathrm{E}-02$ & $1.670 \mathrm{E}-03$ & $1.449 \mathrm{E}-03$ & & & \\
March & $1.828 \mathrm{E}-02$ & $2.880 \mathrm{E}-03$ & $2.616 \mathrm{E}-03$ & $2.282 \mathrm{E}-03$ & $2.176 \mathrm{E}-03$ & $2.128 \mathrm{E}-03$ \\
June & $7.562 \mathrm{E}-04$ & $2.885 \mathrm{E}-05$ & $2.352 \mathrm{E}-05$ & $1.737 \mathrm{E}-05$ & $1.564 \mathrm{E}-05$ & $1.492 \mathrm{E}-05$
\end{tabular}


WSRC-TR-2001-00539

December 2001

$\begin{array}{llllll}\text { October } \quad 5.235 \mathrm{E}-03 & 5.088 \mathrm{E}-04 & 4.261 \mathrm{E}-04 & 3.274 \mathrm{E}-04 & 2.978 \mathrm{E}-04 & 2.850 \mathrm{E}-04\end{array}$ 
Table 3. Cesium Correction Factors as a Function of Release Duration

Month

Downstream Location

In which

Road A

Savannah

US

STATE

Occurred

River

HWY301

HWY119

Beaufort Savannah

Jasper Water Plan

Case 1: $1 \mathrm{~kg}$ cesium released instantaneously

$\begin{array}{lllllll}\text { January } & 1.591 \mathrm{E}-02 & 1.670 \mathrm{E}-03 & 1.449 \mathrm{E}-03 & 1.197 \mathrm{E}-03 & 1.117 \mathrm{E}-03 & 1.083 \mathrm{E}-03 \\ \text { March } & 1.828 \mathrm{E}-02 & 2.880 \mathrm{E}-03 & 2.616 \mathrm{E}-03 & 2.282 \mathrm{E}-03 & 2.176 \mathrm{E}-03 & 2.128 \mathrm{E}-03 \\ \text { June } & 7.562 \mathrm{E}-04 & 2.885 \mathrm{E}-05 & 2.352 \mathrm{E}-05 & 1.737 \mathrm{E}-05 & 1.564 \mathrm{E}-05 & 1.492 \mathrm{E}-05 \\ \text { October } & 5.235 \mathrm{E}-03 & 5.088 \mathrm{E}-04 & 4.261 \mathrm{E}-04 & 3.274 \mathrm{E}-04 & 2.978 \mathrm{E}-04 & 2.850 \mathrm{E}-04\end{array}$

Case 3: $1 \mathrm{~kg}$ cesium released over 300 minutes

$\begin{array}{lllllll}\text { January } & 1.554 \mathrm{E}-02 & 1.657 \mathrm{E}-03 & 1.442 \mathrm{E}-03 & 1.193 \mathrm{E}-03 & 1.113 \mathrm{E}-03 & 1.079 \mathrm{E}-03 \\ \text { March } & 1.784 \mathrm{E}-02 & 2.853 \mathrm{E}-03 & 2.590 \mathrm{E}-03 & 2.275 \mathrm{E}-03 & 2.168 \mathrm{E}-03 & 2.128 \mathrm{E}-03 \\ \text { June } & 7.349 \mathrm{E}-04 & 2.847 \mathrm{E}-05 & 2.330 \mathrm{E}-05 & 1.734 \mathrm{E}-05 & 1.560 \mathrm{E}-05 & 1.482 \mathrm{E}-05 \\ \text { October } & 5.115 \mathrm{E}-03 & 5.048 \mathrm{E}-04 & 4.231 \mathrm{E}-04 & 3.263 \mathrm{E}-04 & 2.966 \mathrm{E}-04 & 2.841 \mathrm{E}-04\end{array}$

Case 4: $1 \mathrm{~kg}$ cesium released over $600 \mathrm{~min}$

$\begin{array}{lllllll}\text { January } & 1.500 \mathrm{E}-02 & 1.611 \mathrm{E}-03 & 1.420 \mathrm{E}-03 & 1.177 \mathrm{E}-03 & 1.101 \mathrm{E}-03 & 1.069 \mathrm{E}-03 \\ \text { March } & 1.726 \mathrm{E}-02 & 2.786 \mathrm{E}-03 & 2.551 \mathrm{E}-03 & 2.245 \mathrm{E}-03 & 2.140 \mathrm{E}-03 & 2.099 \mathrm{E}-03 \\ \text { June } & 6.950 \mathrm{E}-04 & 2.764 \mathrm{E}-05 & 2.281 \mathrm{E}-05 & 1.706 \mathrm{E}-05 & 1.547 \mathrm{E}-05 & 1.470 \mathrm{E}-05 \\ \text { October } & 4.880 \mathrm{E}-03 & 4.931 \mathrm{E}-04 & 4.171 \mathrm{E}-04 & 3.231 \mathrm{E}-04 & 2.936 \mathrm{E}-04 & 2.809 \mathrm{E}-04\end{array}$


WSRC-TR-2001-00539

December 2001

Table 4. Cesium Correction Factors

\begin{tabular}{|c|c|c|c|c|c|c|}
\hline \multirow{3}{*}{$\begin{array}{l}\text { Month } \\
\text { In which } \\
\text { Occurred }\end{array}$} & \multicolumn{6}{|c|}{ Downstream Location } \\
\hline & Road A & Savannah & US & STATE & Beaufort & Savannah \\
\hline & & River & HWY301 & HWY119 & Jasper & Water Plan \\
\hline January & $1.591 \mathrm{E}-02$ & $1.670 \mathrm{E}-03$ & $1.449 \mathrm{E}-03$ & $1.197 \mathrm{E}-03$ & $1.117 \mathrm{E}-03$ & $1.083 \mathrm{E}-03$ \\
\hline February & $1.916 \mathrm{E}-02$ & $2.470 \mathrm{E}-03$ & $2.218 \mathrm{E}-03$ & $1.887 \mathrm{E}-03$ & $1.775 \mathrm{E}-03$ & $1.733 \mathrm{E}-03$ \\
\hline March & $1.828 \mathrm{E}-02$ & $2.880 \mathrm{E}-03$ & $2.616 \mathrm{E}-03$ & $2.282 \mathrm{E}-03$ & $2.176 \mathrm{E}-03$ & $2.128 \mathrm{E}-03$ \\
\hline April & $2.876 \mathrm{E}-03$ & $1.399 \mathrm{E}-04$ & $1.221 \mathrm{E}-04$ & $1.014 \mathrm{E}-04$ & $9.509 \mathrm{E}-05$ & $9.236 \mathrm{E}-05$ \\
\hline May & $1.449 \mathrm{E}-04$ & $1.653 \mathrm{E}-06$ & $1.384 \mathrm{E}-06$ & $1.073 \mathrm{E}-06$ & 9.817E-07 & $9.428 \mathrm{E}-07$ \\
\hline June & 7.562E-04 & $2.885 \mathrm{E}-05$ & $2.352 \mathrm{E}-05$ & $1.737 \mathrm{E}-05$ & $1.564 \mathrm{E}-05$ & $1.492 \mathrm{E}-05$ \\
\hline July & $2.575 \mathrm{E}-03$ & $1.932 \mathrm{E}-04$ & $1.585 \mathrm{E}-04$ & $1.170 \mathrm{E}-04$ & $1.047 \mathrm{E}-04$ & $9.967 \mathrm{E}-05$ \\
\hline August & $1.122 \mathrm{E}-02$ & $1.467 \mathrm{E}-03$ & $1.243 \mathrm{E}-03$ & $9.701 \mathrm{E}-04$ & 8.843E-04 & 8.491E-04 \\
\hline September & 2.823E-04 & 8.413E-06 & $6.865 \mathrm{E}-06$ & $5.079 \mathrm{E}-06$ & $4.572 \mathrm{E}-06$ & $4.355 \mathrm{E}-06$ \\
\hline October & $5.235 \mathrm{E}-03$ & $5.088 \mathrm{E}-04$ & $4.261 \mathrm{E}-04$ & $3.274 \mathrm{E}-04$ & $2.978 \mathrm{E}-04$ & $2.850 \mathrm{E}-04$ \\
\hline November & $1.952 \mathrm{E}-03$ & $8.560 \mathrm{E}-05$ & $7.056 \mathrm{E}-05$ & $5.330 \mathrm{E}-05$ & $4.811 \mathrm{E}-05$ & $4.591 \mathrm{E}-05$ \\
\hline December & $2.332 \mathrm{E}-03$ & $1.117 \mathrm{E}-04$ & $9.607 \mathrm{E}-05$ & 7.734E-05 & $7.158 \mathrm{E}-05$ & $6.923 \mathrm{E}-05$ \\
\hline
\end{tabular}


Table 5. Plutonium Correction Factors

\begin{tabular}{lcccccc} 
Month & \multicolumn{7}{c}{ Downstream Location } \\
$\begin{array}{lccccc}\text { In which } \\
\text { Occurred }\end{array}$ & Road A & $\begin{array}{l}\text { Savannah } \\
\text { River }\end{array}$ & $\begin{array}{l}\text { US } \\
\text { HWY301 }\end{array}$ & $\begin{array}{l}\text { STATE } \\
\text { HWY119 }\end{array}$ & $\begin{array}{l}\text { Beaufort } \\
\text { Jasper }\end{array}$ & $\begin{array}{l}\text { Savannah } \\
\text { Water Plan }\end{array}$ \\
& & & & & \\
January & $7.245 \mathrm{E}-02$ & $1.750 \mathrm{E}-02$ & $1.604 \mathrm{E}-02$ & $1.418 \mathrm{E}-02$ & $1.364 \mathrm{E}-02$ & $1.338 \mathrm{E}-02$ \\
February & $8.121 \mathrm{E}-02$ & $2.242 \mathrm{E}-02$ & $2.101 \mathrm{E}-02$ & $1.903 \mathrm{E}-02$ & $1.840 \mathrm{E}-02$ & $1.799 \mathrm{E}-02$ \\
March & $7.903 \mathrm{E}-02$ & $2.474 \mathrm{E}-02$ & $2.332 \mathrm{E}-02$ & $2.152 \mathrm{E}-02$ & $2.080 \mathrm{E}-02$ & $2.050 \mathrm{E}-02$ \\
April & $2.406 \mathrm{E}-02$ & $3.554 \mathrm{E}-03$ & $3.275 \mathrm{E}-03$ & $2.923 \mathrm{E}-03$ & $2.807 \mathrm{E}-03$ & $2.753 \mathrm{E}-03$ \\
May & $3.413 \mathrm{E}-03$ & $1.986 \mathrm{E}-04$ & $1.780 \mathrm{E}-04$ & $1.520 \mathrm{E}-04$ & $1.443 \mathrm{E}-04$ & $1.406 \mathrm{E}-04$ \\
June & $9.973 \mathrm{E}-03$ & $1.267 \mathrm{E}-03$ & $1.120 \mathrm{E}-03$ & $9.291 \mathrm{E}-04$ & $8.709 \mathrm{E}-04$ & $8.448 \mathrm{E}-04$ \\
July & $2.224 \mathrm{E}-02$ & $4.333 \mathrm{E}-03$ & $3.847 \mathrm{E}-03$ & $3.187 \mathrm{E}-03$ & $2.985 \mathrm{E}-03$ & $2.897 \mathrm{E}-03$ \\
August & $5.735 \mathrm{E}-02$ & $1.591 \mathrm{E}-02$ & $1.450 \mathrm{E}-02$ & $1.242 \mathrm{E}-02$ & $1.169 \mathrm{E}-02$ & $1.142 \mathrm{E}-02$ \\
September & $5.242 \mathrm{E}-03$ & $5.667 \mathrm{E}-04$ & $5.019 \mathrm{E}-04$ & $4.166 \mathrm{E}-04$ & $3.904 \mathrm{E}-04$ & $3.793 \mathrm{E}-04$ \\
October & $3.523 \mathrm{E}-02$ & $8.029 \mathrm{E}-03$ & $7.243 \mathrm{E}-03$ & $6.171 \mathrm{E}-03$ & $5.829 \mathrm{E}-03$ & $5.654 \mathrm{E}-03$ \\
November & $1.863 \mathrm{E}-02$ & $2.584 \mathrm{E}-03$ & $2.296 \mathrm{E}-03$ & $1.936 \mathrm{E}-03$ & $1.820 \mathrm{E}-03$ & $1.767 \mathrm{E}-03$ \\
December & $2.084 \mathrm{E}-02$ & $3.068 \mathrm{E}-03$ & $2.798 \mathrm{E}-03$ & $2.453 \mathrm{E}-03$ & $2.336 \mathrm{E}-03$ & $2.278 \mathrm{E}-03$
\end{tabular}


WSRC-TR-2001-00539

December 2001

Figure 1

Model Schematics for Fourmile Branch (not to scale)

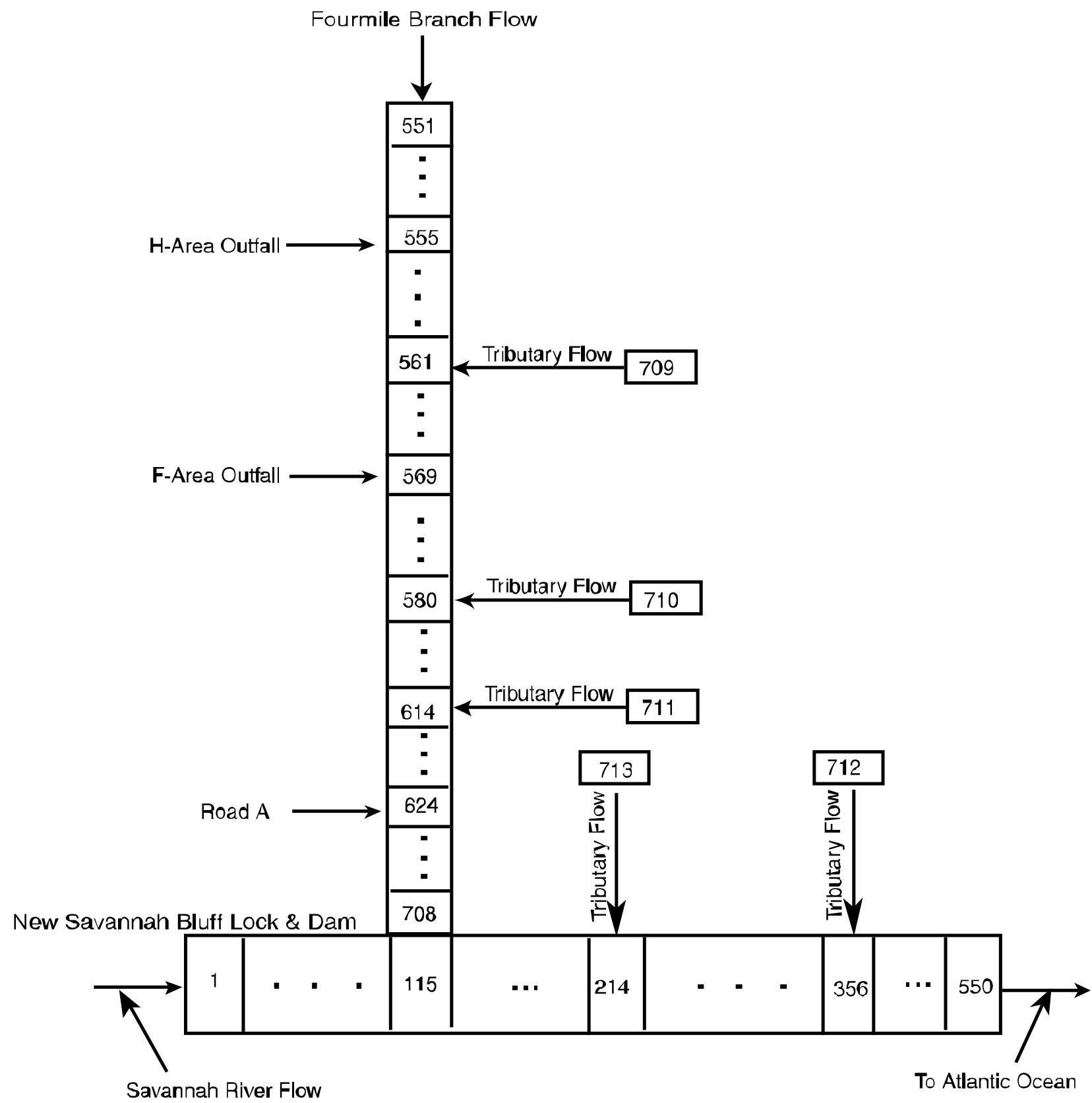


Figure 2

Model Schematics for Fourmile Branch with Benthic Segments (not to scale)

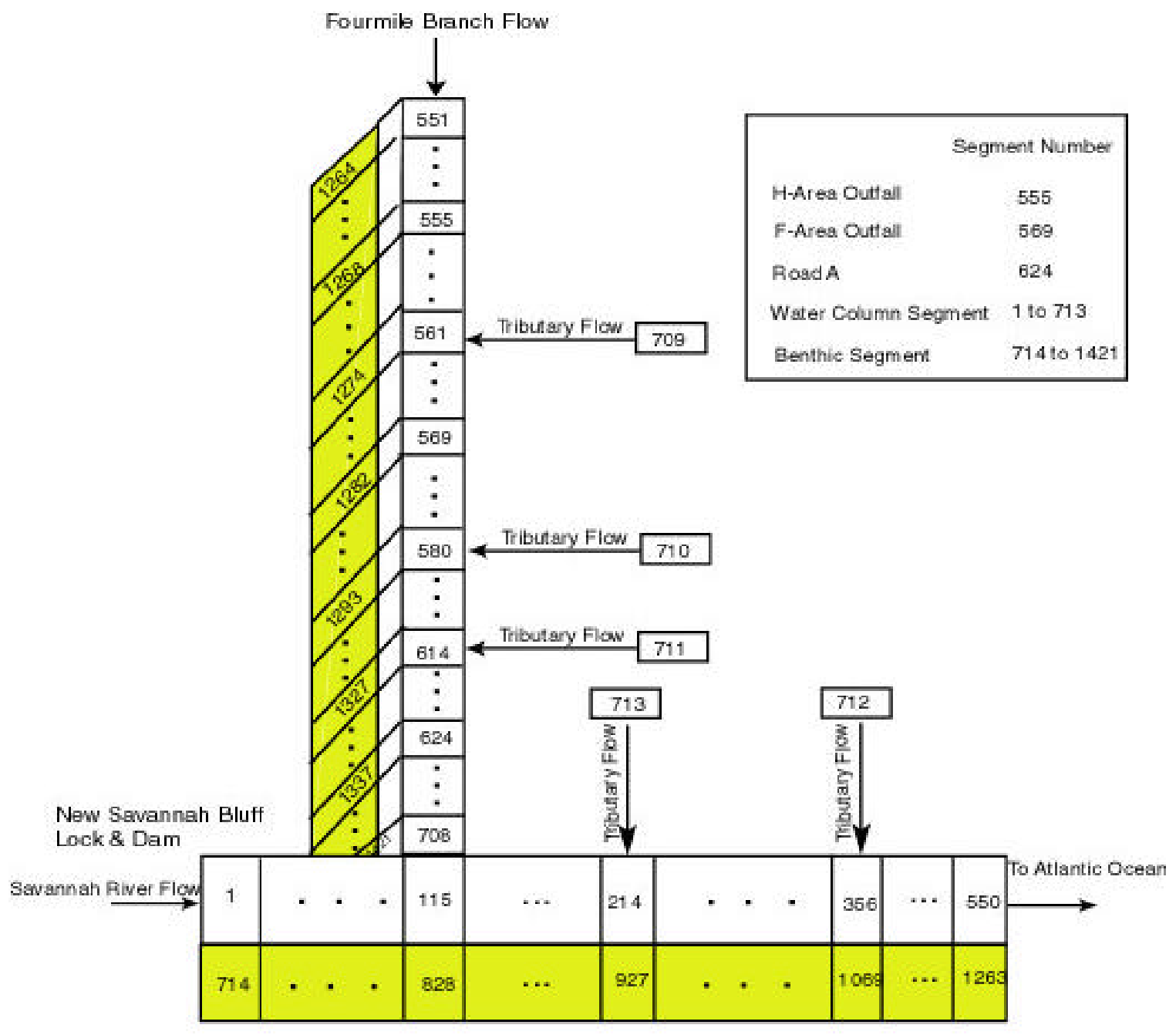


Figure 3. Schematics of Modeled Physical-Chemical Features for Cesium (Plutonium) in Aqueous Transport

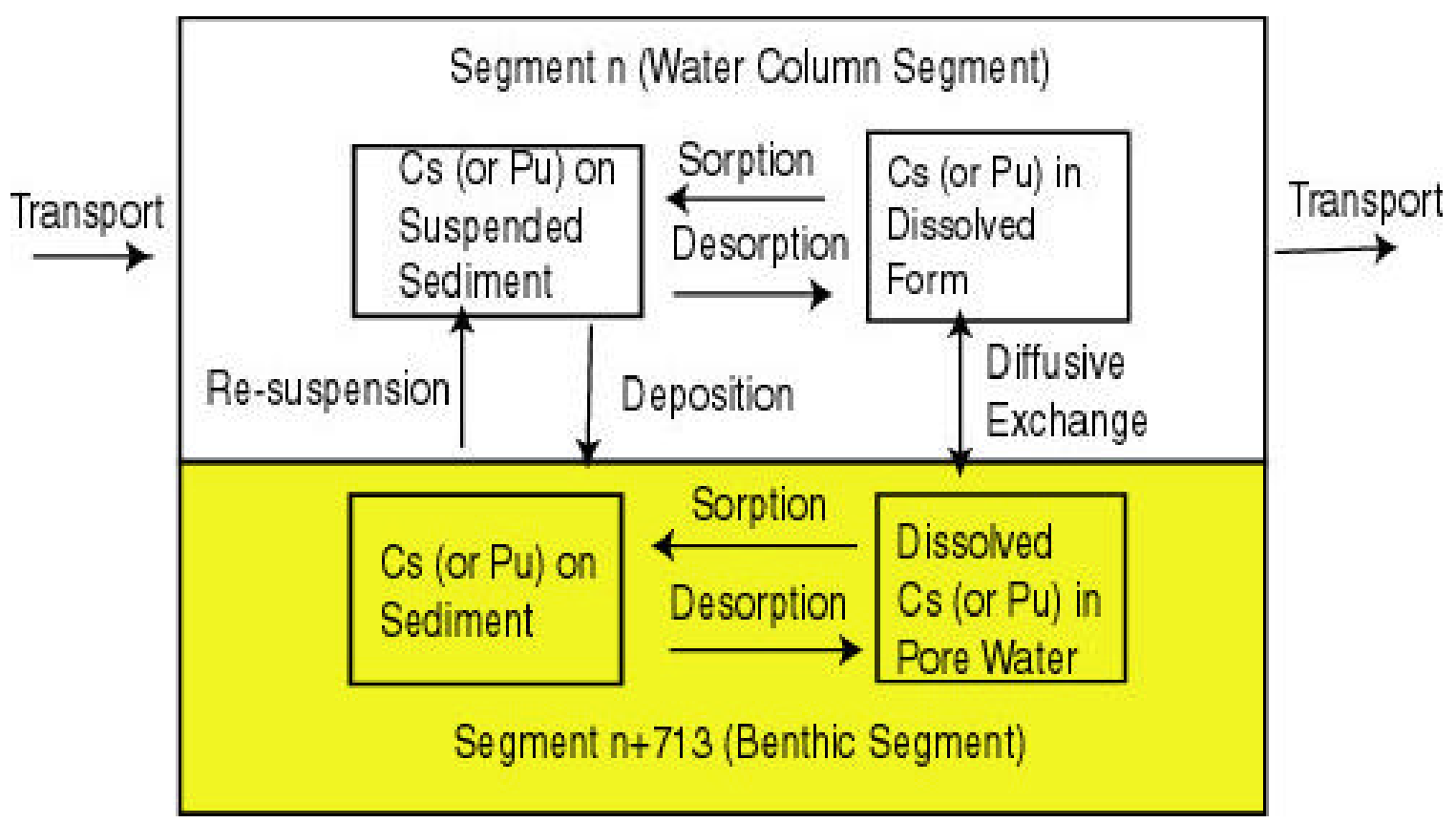

